\title{
The European Union as a Normative Power on the Example of the EU-Turkey Relations
}

\author{
Dominika Liszkowska
}

Institute of Political Science, Kazimierz Wielki University, Bydgoszcz

\begin{abstract}
The aim of this study is to analyze the normative power of the European Union in the relations with Turkey and to answer the question: is the normative power of the European Union effective in relations with Turkey? The work consists of three parts. In the first one, the author analyzes the concept of the European Union as a normative power. The second part is a historical analysis of the relationship between the EU and Turkey. The last part is an analysis of current relations between the European Union (as a Normative Power) and Turkey. The analysis is based on EU's documents.
\end{abstract}

Keywords: Normative Power, The European Union, Turkey, Soft Power, Principles of The EU

\section{Introduction}

The European Union is one of the most important actors in international relations. It is influenced by various factors which come from the outside but at the same time it significantly influences this environment itself. Consequently, the EU has many possibilities of impacting the shape and the course of phenomena and processes which take place in the world. Possibilities which are brought by this impact result from, among others, having a specific potential in a variety of areas (Milczarek, 2005, p. 9). The size of the EU's potential in specific areas affects the scale of the relationship that the organization holds with other actors in international relations. Depending on the type of relationship, the EU partners see it as a significant ally, competitor or opponent (Milczarek, 2003, p. 33).

Actions of the European Union in international relations are not conducted by force, but through peaceful and democratic standards. The civic power of the organization can be characterized by the superiority of diplomatic cooperation and by the resolution of problems and progress in international politics by using transnational institutions (Manners, 2002, p. 236-237). Taking into account the key concept of the civilian role of the European Union on the international stage, attention is drawn to the fact that the EU differs from the traditional great powers because of its unique normative character.

One of the first authors who characterized the normative vision of the European Union's foreign policy was lan Manners. In 2002, he formulated a concept of the European Union as a normative power in international politics (Reichenbach, p. 1). Manners tried to prove that the scope and scale of international actions of the EU can be explained by the concept of the EU's normative power. This concept underlines the EU's need for shaping its global policy. The normative power of the European Union is the power of ideology, opinion, and standards which are set by it. The organization in relations with other entities reaches out to the norms and values which are written in the treaties. The EU not only promotes them but also shows how to implement them (Piskorska, 2013, p. 8). In 2002, Manners pointed out five norms which were included in numerous documents. These are peace, freedom, democracy, rule of law, human rights. In subsequent years, they were supplemented by four more, namely: social solidarity, non-discrimination, sustainable development and good governance (Reichenbach, p. 2).

\section{Normative Power Union - European Identity and Turkey}

\section{The Shaping of the European Identity}

European identity is the result of many centuries of the achievements of European nations. Its composition clearly distinguishes it from the African, Asian and, to a large extent, the nations of both Americas. The identity of Europe was largely created in relation to the Orient. The basic features of Europeanity were shaped by the West-East dichotomy, and the struggle to resist "barbarism" and Islam (Łastawski, 2008, p. 12). 
The triad of European identity consists of the cultural tradition of ancient Greece, the legal tradition of ancient Rome, and Christian universalism (Judeo-Christian traditions). In the past, some "barbarian" traditions also influenced those "European", including Slavs, Normans, Germanic and Celtic peoples. Characteristic values derived from Germans are recognized by the researchers as honor, equality and solidarity, whereas for Slavs freedom and self-government.

Other European values have evolved over the centuries. They are formed by well-developed national cultures, political pluralism, party and trade unionism, established democratic principles, a broad range of human rights (including the prohibition of death penalty), respect for human reason, the rule of law, the separation of church and state (Łastawski, 2008, p. 12).

According to Art. 2 TEU The European Union "is founded on the values of respect for human dignity, freedom, democracy, equality, the rule of law and respect for human rights, including the rights of persons belonging to minorities. These values are common to the Member States in a society in which pluralism, non-discrimination, tolerance, justice, solidarity and equality between women and men prevail" (Consolidated version of the Treaty on European Union). A similar entry can also be found in the preamble to the Charter of Fundamental Rights (CPP), which states "The peoples of Europe, in creating an ever closer union among them, are resolved to share a peaceful future based on common values" (The Charter of Fundamental Rights). As regards the foreign policy of the European Union Art. $3 \mathrm{sec} .5 \mathrm{TEU}$ states that the Union in external relations "shall uphold and promote its values [...] contribute to peace, security, the sustainable development of the Earth, solidarity and mutual respect among peoples [...] and the protection of human rights". On the other hand, a member of the EU can remain "any European State which respects the values referred to in Article 2 and is committed to promoting them" (Art. 49, Consolidated version of the Treaty on European Union).

\section{The concept of European Identity within the Framework of the Essentialist and Constructivist Approach}

Collective identity can be analyzed through two approaches. The first one is the essentialist approach which treats the issue of identity as an essential characteristic of a given social group. This is something that can be considered as its unchanging essence. The basis here consists of the belief in common origin. This is the reason for the supporters of the essentialist concept to seek the real (historical) basis of cultural identity (Skrzypczak, 2010, p. 206). The second one is the constructivist approach which defines identity as the effect of the creation process (or even as the process itself). Within this approach, identity is not considered as an existing entity, but as something that is created and is a subject to change.

European identity is, therefore, not easily defined by an essential (ethnic) approach. The reason for this is the fact that the European heritage, through which it would be possible to construct this identity, is too diverse. The identity of Europeans is also difficult to build in relation to one and common to all "significant other". This could be, for example, Islam. However, at the same time a common identity would be built on an "antagonistic and anti-Islamic" basis.

The issue of European identity can be explained somewhat differently in the case of constructivist insights. In this case, identity is understood as a common European project and its place can be found in the entire spectrum of diversity. Because of its place of origin or cultural heritage, any entity cannot be excluded. However, this is not the reason for the lack of borders as regards the question of recognizing someone as a European. Europe is a process of constructing a community through joint action. Therefore, it must be based on common, negotiated, fundamental principles, rights and values.

It is, therefore, necessary that these values are not mutually exclusive and that every potential member may be involved in the community through them (ec.europa.eu). The European Union is a negotiated project. Its implementation requires acceptance of values. The EU Values Area is defined in the Treaties and the Charter of Fundamental Rights and defines the conditions for joint building of the European Union, as well as its European identity.

\section{The Identity of Turkey and the European Union}

Since the beginning of the European Union, its membership has been conditioned by "democratic credentials"'. Over time, identity has become also increasingly important. According to some researchers, the overwhelming majority of EU members have created a discursive framework through which their identity can be integrated into the so-called "Supra-nationalist" European identity and this framework does not include any state outside the European circle (Barker, 2012, p. 18).

In the creation of European civilization, the Roman Empire and Christianity played a constructive and unifying role. Identifying someone as a European is not just about living in a given region of the world but also about sharing and practicing common traditions, histories, norms and values. Membership in the European Union is considered to be "the most 
significant determinant of Europeanness" (Bac, Taskin, 2007, p. 38), while Member States have a common understanding of common heritage.

According to some scholars, Turkey cannot be considered a state that shares its Christian heritage and rationalistic traditions (recognized as the basis of European identity). For the opponents of this reasoning, it is important that the Byzantine and Ottoman empires also influenced the shape of Europe. By contrast, with Atatrük's reforms Turkey has chosen the European orientation, its political institutions and the idea of a secular state (Littoz-Monnet, Penas, p. 7). However, in the history of Europe, the Turks have always been recognized as the so-called "other", whereas Turkish/Ottoman influences (like Arab or Jewish) have been seen as foreign influences. Therefore, it is difficult to incorporate them into a common culture and religion that shapes what can be defined as the European heritage and European identity (Tekin, 2005, p. 292).

Buzan and Diez noted that further EU integration with Turkey would jeopardize the social and political self-identification of both of these subjects (Littoz-Monnet, Penas, p. 292), whereas Kevin Robins believes that Turkish culture "disturbs the order of Europe" and that as a some sort of "hybrid" it still does not meet the European standards (Robins, 1996, pp. 6566). However, according to Bahar Rumelili, the construction of dichotomy between Europe and Asia, as well as the West and Islam, which are two contradictory and mutually exclusive identities, has been a cornerstone in the European Union's relations with Turkey. Such divisions have caused Turkey to become "partially itself, [partly] and partially the other part" (Rumelili, 2008, p. 102). Turkey is a country of contradictions located on two continents where the society of Islamic majority exists together with the Western concept of secular state, based on the rejection of the Ottoman and Islamic heritage.

The Turks are a nation strongly attached to their identity, and adopting European patterns could become a threat to them. For Turkish citizens, integration with EU structures is a mean of tackling poverty and economic problems rather than abandoning their own cultural heritage (Szkudlarek, 2012, p. 264).

In a Eurobarometer survey in May 2015, $40 \%$ of Turkish respondents said that Turkey's membership in the EU would be "bad" for the state (a $5 \%$ increase compared to the Eurobarometer survey 6 months earlier). However, $55 \%$ of respondents agreed that Turkey would benefit from EU membership (19\% more than in the previous survey). By contrast, $36 \%$ of the respondents claimed that the country would not benefit from the membership (dailysabah.com).

On the other hand, European citizens see Turkey's membership in the European Union as a cause for concern over "turkification". It is understood as the cultural expansion of the Turks, who after the accession would have exactly the same rights as citizens of the EU member states. It can be assumed that the fear of "turkification" is not as much a result of aversion to a foreign culture (although it cannot be ruled out, despite the fact that many Muslims have been living in EU member states for years) as some uncertainty about the number of Turks who could come to Europe after Turkey's accession to the Union. The hallmark of "turkification" is the universality, which means the mass phenomenon of importing unlike European cultural patterns which are not always accepted by the Europeans (Szkudlarek, 2012, p. 264).

\section{Turkey's relations with the European Union}

Turkey has already applied for membership in the European Communities in 1987. However, the answer to the accession was negative (Gwiazda, 2005, p. 3). There were indications of numerous irregularities in the political, social and economic spheres (Ciechurska, 2014, p. 103).

In December 1999 in Helsinki, Turkey became the official candidate for the membership of the UE (Szymański, 2008, p. 7) and, like the rest of the candidates, the state was involved in the pre-accession process. The pre-accession process was primarily concerned with the need to introduce reforms, mainly in terms of political criteria and human rights issues (Ciechurska, 2014, p. 104). In "Accession Partnership" adopted in March 2001 by the EU Council, the main issue was the abolition of the death penalty and the signature of Protocol 6 to the European Convention on Human Rights (ECHR). Regulations on this matter were finally adopted on 8 May 2004 by The Grand National Assembly of Turkey. The new provisions introduced in the Basic Law did not allow any case of death penalty ("no one can be sentenced to death penalty", Article 38 (7)) (Szymański, 2008, pp. 108-111).

In 2003, the European Commission in its Strategic Document stated that Turkey was able to speed up the pace of reforms and make decisive efforts and progress towards compliance with the Copenhagen Criteria. It has also been noted that considerable progress has been made towards achieving economic criteria. On the other hand, the task that was given to 
Turkey was the continuation of progress towards the fulfillment of the acquis criteria because in spite of many changes further efforts would be necessary (Üçer, 2006, p. 211).

The decision to start the accession negotiations was made at the Brussels summit in December 2004. This was in line with the plan of 3 October 2005 after Turkey fulfilled two preconditions (Jurkowska, 2009, p. 12). The first condition was the enlargement of the Protocol extending the EU-Turkey customs union (the EU-Turkey customs union have been in force since 1 January 1996) (Gwiazda, 2005, p. 3) to 10 more EU Member States. This condition has been fulfilled, however, Turkey has claimed that the extension of the customs union to Cyprus does not imply recognizing it as a state (Jurkowska, 2009, p. 16). Condition two was the entry into force of six pieces of legislation, including the Code of Criminal Procedure and the Criminal Code.

\section{Values or European interests in relations with Turkey?}

For many years, the accession process of Turkey has been in the state of stagnation. According to some researchers, the situation was "comfortable" for the EU. The customs union between the EU and Turkey (since 1996), which opened up the markets, has brought much greater benefit for the Community than for the other side (Czachór, Graś, 2006, pp. 210-211). It was only at the moment of the immigration crisis which began to be faced by the European Union that some moves towards strengthening the mutual relations were made. On 29 November 2015 an EU-Turkey summit was held (Rada Europejska, 2014). At the summit the need to "revive" Turkey's accession to the EU was and deepening of bilateral dialogue was recognized. During the meeting sides agreed on the issues of acceleration of visa liberalization between parties. The European Union has declared the abolition of visas for Turkish nationals even in the autumn of 2016 if certain conditions are met (including the implementation of the readmission agreement by Turkey which was supposed to happen in June 2016) (IAR/PAP, banier.pl).

The decision to organize an intergovernmental conference finally took place on 14 December 2015. The 17th edition of the "Economic and Financial Policy" Accession Negotiations, which was the first "new" technical point, was agreed upon after almost a two-year break (pl.sputniknews.com).

On 14 April 2016, the European Parliament adopted a resolution on Turkey. It defined Turkey as a "key strategic partner for the EU". Of particular note was the reception and protection of about 2 million Syrian refugees by Turkey. The resolution also supported the idea of making Turkish one of the official languages of the European Union (EurActiv.pl).

However, already in the April 2016 in the report on the subject of Turkey, the European Parliament (EP) expressed deep concern about the deviations from respect for democracy and the rule of law. It was claimed that the overall pace of reforms in this country in recent years has decreased significantly. Visible regress has been noted in areas such as the independence of judiciary system, freedom of assembly, freedom of expression, respect for human rights and the rule of law. As a result, Turkey has got farther from meeting the Copenhagen Criteria (European Parliament, 2016). There was, however, a revival in the negotiation process and it was hoped that the opening of new chapters would lead to actual progress. Turkey has also been called for "real involvement" in this area. The report supported the idea of a more frequent and open high-level political dialogue on key issues including migration, the fight against terrorism, energy, trade and the economy.

The important issue highlighted in this resolution is the postponement of the publication of the European Commission (EC) report on Turkey's progress with respect to the elections held in that country in November 2015. It was judged to have been a bad decision which left an impression that the European Union "was ready to be silent on the violation of fundamental rights in exchange for cooperation with the Turkish government on refugees" (European Parliament, 2016). The European Commission has also been asked to publish progress reports in accordance with a timetable and findings. They also urged the Commission and the Council not to ignore the internal turmoil in Turkey and, independently of other interests, clearly expressed their respect for the rule of law and fundamental rights in the country as specified in the Copenhagen Criteria (European Parliament, 2016).

\section{Summary}

Contrary to the view of Western media that the Turkish people adopted democracy in its European meaning, the people of Turkey began to oppose the announcement of the alignment of the legal or political system with EU norms. The process of Europeanisation, characterized by intense cooperation between authorities, began to face difficulties within these reforms 
which aimed at making Turkey resemble member states of the EU. The Turks over the years, without a guarantee of success, have been fulfilling the criteria (tightened from time to time by the EU institutions). However, after some time the attitude of Turkey started to be characterized by discouragement and fatigue in response to the situation created by Brussels. As a result, further Europeanisation of Turkey may not be possible. The reason for this situation does not have to be found in the suspension of the membership negotiations by the EU side or the reluctance towards achieving membership on the side of Turkey.

\section{References}

[1] Bac M. M., Taskin E. (2007), Turkey's Accession to the European Union: Does Culture and Identity Play a Role?, "Ankara Review of European Studies", vol. 6, no. 2.

[2] Barker J. P. (2012), Turkish Religious Identity and the Question of European Union Membership, http://www.culturaldiplomacy.org/academy/content/pdf/participant-papers/2012-04-ankara/Turkish-Religious-Identity-andthe-Question-of-European-Union-Membership--J-Paul-Barker.pdf, accessed: 15.06.2017.

[3] Charter of Fundamental Rights of the European Union (2012/C 326/02).

[4] Ciechurska A. (2014), Aspiracje Turcji dotycz?ce cz?onkostwa w Unii Europejskiej, "Studia i Analizy Europejskie", no. 12.

[5] Consolidated versions of the Treaty on European Union and the Treaty on the Functioning of the European Union (2012/C 326/01).

[6] European Parliament resolution of 14 April 2016 on the 2015 report on Turkey (2015/2898(RSP)).

[7] Gwiazda A. (2005), Cz?onkostwo Turcji w Unii Europejskiej - szanse i zagro?enia, "Wspólnoty Europejskie", no. 10 (167).

[8] Jurkowska B. (2009), Negocjacje Turcji z Uni? Europejsk? - stan i perspektywy, "Wspólnoty Europejskie", no. 6 (199).

[9] Littoz-Monnet A., Penas B. V., Turkey and the European Union the Implications of a Specific Enlargement, http://aei.pitt.edu/9307/1/050404Turquie-ALM-BVP.pdf, accesed: 15.06.2017.

[10] ?astawski K. (2008), Polsko?? i europejsko?? w procesie integracji kontynentu, "Studia Europejskie", no. 1.

[11] Manners I. (2002), Normative Power Europe: A Contradiction In Terms, "JCMS", vol. 40, no. 2.

[12] Milczarek D. (2005), Potencja? UE w stosunkach mi?dzynarodowych (cz??? 1), "Studia Europejskie", no. 1.

[13] Milczarek D. (2003), Rola mi?dzynarodowa UE jako "mocarstwa niewojskowego, "Studia Europejskie", no.1.

[14] Piskorska, B. (2013), Warto?ci czy interesy? Europejska Polityka S?siedztwa jako test na efektywno?? normatywnej si?y Unii Europejskiej w stosunkach mi?dzynarodowych, "Analiza Natoli?ska", vol. 11.

[15] Reichenbach, T., A brief survey on 'Normative Power Europe', Celsius, http://www.celsius-europe.eu/?page_id=12, accesed:15.11.2014.

[16] Robins K. (1996), 'Interrupting Identities: Turkey/Europe', [in:] Questions of Cultural Identity, S. Hall, P.D. Gay (ed.), London.

[17] Rumelili B. (2008), Negotiating Europe: EU-Turkey Relations from an Identity Perspective, "Insight Turkey", vol. 10, no. 1.

[18] Skrzypczak K. (2010), Jaka to?samo?? kulturowa dla dzisiejszej Europy, "Refleksje", no.1.

[19] Szkudlarek M. (2012), Turcja w Unii Europejskiej? Bilans korzy?ci i kosztów, "Przegl?d Strategiczny", no. 1.

[20] Szyma?ski A. (2008), Mi?dzy Islamem a Kemalizmem. Problem demokracji w Turcji, Warszawa.

[21] Tekin A. (2005), Future of Turkey-EU relations: a civilisational discourse, "Futures", no.37.

[22] Üçer E. (2006), Turkey's accession to the European Union, "Futures", no. 38.

[23] Links:

[24] http://ec.europa.eu/polska/news/opinie/090629_tozsamosc_europejska_pl.htm, accesed: 15.06.2017.

[25] https://www.dailysabah.com/eu-affairs/2015/08/03/turkish-people-indecisive-over-eu-membership-survey-reveals, accesed: 15.06.2017.

[26] Rada Europejska, Rada Unii Europejskiej, Szczyt przywódców UE z Turcj?, 29.11.2015 - O?wiadczenie UE-Turcja, http://www.consilium.europa.eu/p//press/press-releases/2015/11/29-eu-turkey-meeting-statement/, accesed: 30.09.2016.

[27] IAR/PAP, Porozumienie UE z Turcj? o wspó?pracy w sprawie migracji, http://www.bankier.pl/wiadomosc/Porozumienie-UEz-Turcja-o-wspolpracy-w-sprawie-migracji-3448863.html, accesed: 30.09.2016.

[28] Turcja i UE osi?gn??y porozumienie ws. kolejnego punktu euro integracji, "Sputnik Polska", http://pl.sputniknews.com/polityka/20151214/1647654/Turcja-UE-integracja.html, accesed: 30.09.2016.

[29] Kk, Raport ws. Turcji przyj?ty, "EurActiv.pl, http://www.euractiv.pl/wersja-do-druku/artykul/raport-ws-turcji-przyjty-008317, accesed: 30.09.2016. 